\title{
A Study on Association with Abiotic Factors and Modelling Incidence of Soil Borne Nematodes in Tuberose (Polianthes tuberosa L.)
}

\author{
Sh. Herojit Singh ${ }^{1}$, Md. Noman ${ }^{1}$, Kushal Roy ${ }^{2}$, Soumik Dey ${ }^{1}$, Lakshmi Narsimhaiah ${ }^{1}$, \\ Pramit Pandit ${ }^{1}$ and P.K. Sahu ${ }^{{ }^{*}}$
}

${ }^{1}$ Department of Agricultural Statistics, ${ }^{2}$ Department of Agricultural Entomology, Bidhan Chandra Krishi Viswavidyalaya, Mohanpur-741252, India

*Corresponding author

Keywords

Tuberose, Soil nematodes, Abiotic factors, Parametric trend

Article Info

Accepted:

22 January 2019

Available Online:

10 February 2019

\section{A B S T R A C T}

Tuberose (Polianthes tuberosa L.) occupies a very selective and special position among the ornamental bulbous plants which are valued much by the aesthetic world for beauty and fragrance. Tuberose is cultivated in large scale in many tropical and subtropical countries including India. It is an important cash crop in India and commercial cultivation is taking place in Karnataka, Andhra Pradesh, Tamil Nadu, Maharashtra and West Bengal. During 2014-15 total area under tuberose in India was 6.82 thousand hectares producing 42.74 thousand MT and 5.93 lakhs pikes (Anonymous, 2015). Comparatively low productivity in West Bengal is attributed to incidence of pests including nematodes besides other problems. Farmers are often unaware of losses caused by nematodes infestation because the damage is so subtle that it goes unnoticed or is attributed to other causes. In this study an attempt has been made to study incidences of different soil borne nematodes and model nematode incidences using various parametric trend models in tuberose cultivation using experimental data during 2014-16. The study reveals that not all abiotic factors are equally significantly associated with the incidence of different soil borne nematodes. Among various parametric trend models mostly polynomial trend models are well fitted except in a few cases where exponential trend models are fitted to nematode incidence in tuberose.

\section{Introduction}

Flowers are associated with mankind from the dawn of civilization. It is said that in India man is born with flowers, lives with flowers and finally dies with flowers. Flowers are used for various purposes in our day to day life like worshipping, religious and social functions, wedding, interior decoration and self-adornment (Bose, 1995). Among the ornamental bulbous plants which are valued much by the aesthetic world for beauty and fragrance, tuberose (Polianthes tuberosa L.) occupies a very selective and special position to flower loving people. The flowers emit a delightful fragrance and are the source of tuberose oil which is used in high value perfumes and cosmetic products and there are many other uses of its bulbs also. As such it is treated as cash crop in India and mostly 
cultivated in Karnataka, Andhra Pradesh, Tamil Nadu, Maharashtra and West Bengal.

During 2014-15 total area under tuberose in India was 6.82 thousand hectares producing 42.74 thousand MT and 5.93 lakhs pikes (Anonymous, 2015).

Nematodes are diverse metazoans with an estimated total number of a million species (Lambshead, 2004). They are arguably the most numerous metazoans in soil and aquatic sediments.

A tuberose field can be damaged due to pest attacks causing a maximum damage up to 74 per cent (Khan et al., 2005). Root knot nematodes cause suppression of spikes and even absolute loss of flower in severe cases in tuberose (Rajendran and Muthukrishnan, 1980).

Considering the quantum of damage it is necessary to have control measures for tuberose pests. Thus, knowledge about the pests, their association with the abiotic factors, and also modelling the path of incidences during different parts of the year is necessary to ensure against any crop failure.

The study aims to study available population of soil borne nematodes infesting on tuberose and effect of various abiotic factors on these nematodes.

\section{Materials and Methods}

To accomplish data requirement a fixed plot experiment was conducted with the help of All India Coordinated Research Project (AICRP) on nematodes of cropping system at Gyaespur Central Research Farm of Bidhan Chandra Krishi Viswavidyalaya, Nadia, West Bengal during the years, 2014-15 and 201516. The experiment was conducted at the new alluvial zone which lies between $22^{0} 53^{\prime}$ and $24^{\circ} 11^{\prime}$ (North latitudes) and $88^{\circ} 09^{\prime}$ and $88^{\circ} 48^{\prime}$ (East longitudes).

Extensive data of nematodes infesting on Tuberose were collected fortnightly using fixed plot technique during two years, 201415 (May, 2014 to April, 2015) and 2015-16 (May, 2015 to April, 2016) along with various micro-climatic factors say soil moisture, soil temperature, ambient temperature at $7 \mathrm{am}$, ambient temperature at 9 am, ambient temperature at $11 \mathrm{am}$, relative humidity $(\mathrm{RH})$ at $7 \mathrm{am}, \mathrm{RH}$ at 9 am and $\mathrm{RH}$ at $11 \mathrm{am}$. Standard package of practice without any insecticide was followed throughout the growing period.

Soil samples were collected from rhizosphere of tuberose crop to a depth of $15 \mathrm{~cm}$, from twelve place of the entire experimental area. Nematode were extracted from composite soil samples (200cc each) by Cobb's decanting and sieving technique (Cobb, 1918) followed by modified Baermann's funnel method (Christie and Perry, 1951) and nematodes are identified by Seinhorst's glycerol-ethanol method.

\section{Correlation coefficient}

To measure the degree of linear association Karl Pearson's correlation coefficients between any two variables $(\mathrm{x}, \mathrm{y})$ is used and given as

$r_{x y}=\frac{\operatorname{Cov}(x, y)}{s_{x} \cdot s_{y}}$ where $s_{x}$ and $s_{y}$ are sample standard deviations of $x$ and $y$.

\section{Parametric trend model}

Different parametric models (Linear, Quadratic, Compound, Exponential, Power, Growth, Cubic etc.) will be used to model nematode incidence in tuberose (Table 1). 


\section{Results and Discussion}

\section{Occurrence of soil nematode in tuberose in 2014-15}

Soil nematodes are broadly categorized into two groups, namely plant parasitic nematodes and non-plant parasitic nematodes. In this study five plant parasitic nematodes, Meloidogyne incognita, Hoplolaimus indicus, Helicotylenchus dihystera, Aphelenchus avenae, Rotylenchulus reniformis and two non-plant parasitic nematodes, Mononchus sp. and Saprozoic sp. were found infesting tuberose. Number of Meloidogyne incognita per 200cc of soil sample was found ranging from zero to 12.21 with an average of 2.53. Positive value of skewness (1.46) and kurtosis value (0.76) reveal that maximum occurrence has taken place during the initial fortnight of the year. The average number of Hoplolaimus indicus was 87.06 with the highest number 201.25 that is almost $132 \%$ higher than mean while the minimum number recorded was 29.25. Rotylenchulus reniformis shows maximum average among all plant parasitic nematodes i.e. 431.14 , it was more than sum of other four plant parasitic nematodes. Distributions of all plant parasitic nematodes are positively skewed and leptokurtic with minimum counts lower than the average revealing steady increase of these nematodes in initial period and remain almost same during rest of the time period of study. Average number of total plant parasitic nematodes was 549.58. In the first year average count of parasitic nematodes is higher than non-parasitic nematodes (Table 2).

From the study of both parasitic and nonparasitic nematodes it is found that during the early fortnight of the year nematode load is comparatively higher than the later fortnights. This may be due to the congenial abiotic conditions required for the development of the nematodes. Patel el al., (1999) reported that low variation in minimum and maximum temperature and high relative humidity are favorable for pest outbreak. Some of the congenial abiotic factor like soil temperature and soil moisture etc. similarly the platykurtic nature of almost all the nematodes indicate that once the nematode load is established in the soil it continues as we have not opted for any control measures.

\section{Occurrence of soil nematode in tuberose in 2015-16}

Meloidogyne incognita counts got reduced in the second year. In case of Rotylenchulus reniformis counts increased and the highest number recorded was2334.29. The second year marked the lowest average count of Mononchus sp. but Saprozoic sp. increased slightly. Average Total plant parasitic nematode count got highly increased to 1799.64. During this period average plant parasitic nematodes was more than 2.5 times of non-plant parasitic nematodes that is 1799.64.In 2015-16,average Total nematode count was 2442.96and it is more than that was in2014-15. It is a clear indication that number of nematode increasing with time (Table 3 ).

Comparing the descriptive statistics for two different years with respect to occurrence of different soil borne nematodes, it has been found that nematode loads were comparatively higher during second year. But one common features of occurrence of nematode is that each year nematode loads are found to be during the early fortnight and the load continues for rest of the years. If we compare the descriptive statistics table 4 and 5 for micro climatic factors, we can suggest that changes in microclimatic factors under study have taken place during latter fortnight of the years, as depicted by skewness of all the factors, but by that time nematode loads in soil have already established and as a result micro climatic factors have little impact on 
the already established nematode loads in soil in spite of their significant association with nematode occurrence.

\section{Occurrence of soil nematode in tuberose (2014-16)}

Having noted the year wise occurrence pattern of different species of nematodes, in this section has been made to examine the overall pattern of occurrence during the whole period of study. When data for two years are combined it shows that counts of parasitic nematodes is almost double the counts of nonparasitic nematodes. Rotylenchulus reniformis has the maximum average counts among all plant parasitic nematode, 1045.76 which is more than sum of other four nematode counts. Total count of plant parasitic nematodes ranges from 218.36 to 2429.99 with an average value of 1174.61. Average number of Meloidogyne incognita per 200cc soil sample was found as 1.73 which was the minimum among all the plant parasitic nematodes considered. Average number of Hoplolaimus indicu was 56.21 with maximum count of 201.25 that is almost $258 \%$ higher than mean. In case of Helicotylenchus dihysteraaverage number of count was 68.54 with a maximum value of 213.45 that is more than three times the average (68.54) (Table 7).

Distribution of the incidence of most of the species of nematode was found positively skewed and platykurtic indicating maximum increase of their incidence at the initial period and then decreases and remains flat during rest of the time period of study.

Micro climatic factors during the experimental period in tuberose in 2014-15

Intensity of soil borne nematodes and other pests are influenced by microclimatic factors. Srivastava (1993) reported that temperature and humidity directly affect the pest populations. In this direction we have studied the microclimatic factors during the study period. The average soil moisture percentage was $10.06 \%$ with highest being at $16.36 \%$, while the minimum soil moisture percentage was $2.83 \%$. The maximum soil temperature in tuberose field was $31.50^{\circ} \mathrm{C}$ and the lowest $10.12^{\circ} \mathrm{C}$. The average ambient temperature were $(24.33,27.96 \text { and } 32.47)^{0} \mathrm{C}$ respectively at $7 \mathrm{am}, 9 \mathrm{am}$ and $11 \mathrm{am}$. The average relative humidity was $83.92 \%, 74.38 \%$ and $60.30 \%$ during 7 am, 9 am and 11 am respectively.

\section{Micro climatic factors during experimental period in tuberose in 2015-16}

The average soil moisture was $8.9 \%$ with the highest being $12.91 \%$, while the minimum soil moisture percentage was $3.46 \%$.Compared to previous year, average soil moisture is less during 2015-16. The maximum soil temperature was recorded as $31.45^{\circ} \mathrm{C}$ and the lowest as $10.12{ }^{\circ} \mathrm{C}$ (Table 6). The average ambient temperature were (23.82, 27.4 and 32.07) ${ }^{0} \mathrm{C}$ respectively at 7 am, 9 am and $11 \mathrm{am}$. There is not much change in average ambient temperature as compared to that of previous year. The average relative humidity was $84.09 \%$, $70.61 \%$ and $58.47 \%$ during 7 am, 9 am and 11 am respectively. Maximum and average values of soil moisture and $\mathrm{RH}$ are lower than those of first year.

\section{Correlation of abiotic factors and soil nematode in tuberose in 2014-15}

Abiotic factors are supposed to have a great role in soil nematode incidences of tuberose. In this section attempts have been made to work out their degree of linear association with the incidence of soil nematodes on tuberose using Karl Pearson's correlation coefficient. From table 8 it clear that Meloidogyne incognita, Hoplolaimus indicus, Helicotylenchus dihystera and Mononchus sp. have significant positive correlation with soil 
moisture, soil temperature, and ambient temperature at $(7,9$ and 11) am. Rotylenchulus reniformis has a significant negative correlation with soil moisture. Rotylenchulus reniformis, Saprozoic sp., total plant parasitic nematode, total non-plant parasitic nematode and total nematode have significant negative correlation with relative humidity at $7 \mathrm{am}$ and $9 \mathrm{am}$.

\section{Correlation between abiotic factors and soil nematode in tuberose in 2015-16}

In the second year also the study assumed that the abiotic factors are supposed to have a greater role in soil nematodes incidences in tuberose. Soil moisture and relative humidity at 7 am have negative significant correlation with Rotylenchulus reniformis and Total plant parasitic nematodes. There is also significant negative association of relative humidity at 7 and 9 am with Total nematodes. Total plant parasitic nematode and Total nematode have significant positive effects from soil temperature, ambient temperature at 7 and 9 am. Meloidogyne incognita and Rotylenchulus reniformis also have significant positive association with ambient temperature at $7 \mathrm{am}$. Rotylenchulus reniformis was found increased as soil temperature rises. There were no significant associations of nematodes with ambient temperature and relative humidity at 11 am during the second year (Table 9).

\section{Correlation between abiotic factors and soil nematode in tuberose in 2014-16}

Likewise 2014-15 and 2015-16 in this section we took whole study period to examine the association of soil nematode incidences in tuberose with abiotic factors. Meloidogyne incognita, Hoplolaimus indicus, Helicotylenchus dihystera and Mononchus sp. have significant positive correlation with soil moisture, soil temperature, ambient temperature at (7,9 and 11) am which is the same result found in the first year. Soil moisture, ambient temperature at (7,9 and 11) am have positive significant association respectively with incidence of Helicotylenchus dihystera and Aphelenchus avenae (Table 10). Relative humidity at 7 am has significant negative impact on the incidence of Rotylenchulus reniformis, Saprozoicsp., total plant parasitic nematode, total non-plant parasitic nematode and total nematode on tuberose. Combining data for the two years gives almost the same result as the first year.

Trend analysis of soil nematode in tuberose using parametric model (2014-15)

Knowing the above overall performance, path of movement of the nematode incidences data are traced through parametric trends models. To workout the trends in soil nematodes different parametric model like Linear, Quadratic, Cubic, Exponential, Gompertz, Compound, Logarithmic and Growth models are attempted. Among the competitive models, the best model is selected on the basis of the maximum adjusted $\mathrm{R}^{2}$ value, minimum RMSE and MAPE with significant model coefficients. The following section presents the results of these exercises.

From the trend analysis (Table 11), one can see that data follow non-linear pattern of movement during the study period in all the nematode series. Temperature $(28.5-29.6)^{0} \mathrm{C}$ and relative humidity $(83.5-86.5 \%)$ play an important role in growth and development of nematode population (Khan and Pal, 2001).

Nematode intensity occurred maximum after rain and minimum during pick summer season that may be the reason that maximum nematode series follow non-linear model. Except Meloidogyne incognita, Hoplolaimus indicus and Saprozoic sp. all other series follow polynomial trend model there by 
indicating more than one point inflections. Pal (2011) reported that polynomial trend model was best fitted in the incidences of Brinjal and Chilli pest in new alluvial zone.Meloidogyne incognita and Hoplolaimus indicus decrease exponentially during the year. Aphelenchus avenae follows a declining cubic trend, maximum intensity was found during June and minimum during January to February. Intensity of Rotylenchulus reniformis increases over time and has more than one point inflections.

Maximum intensity of Mononchus sp. was found during June-July and in winter season it reduces to almost zero. Saprozoic sp. also follow a declining cubic trend, minimum intensity was found during last of August and maximum during July. Population of total plant parasitic nematode was increasing with the increase of maturity of the crop thereby proper management should be taken up in time so that the damage could be minimized. Total non-plant parasitic nematodes follow power functions. Total nematodes load in the soil follow a quadratic trend. From early stage of the crop nematode load in soil is decreasing and then further increasing from January onwards. Maximum intensity was found during March and minimum during September.

\section{Trend analysis of soil nematode in tuberose using parametric model in 2015-16}

Likewise 2014-15 we consider parametric trend analysis of 2015-16 data series also. To workout the trends in soil nematodes different parametric model like Linear, Quadratic, Cubic, Exponential, Gompertz, Compound, Logarithmic, Growth models as discussed in Material and Method section are attempted to. Among the competitive models the best model is selected having maximum $\mathrm{R}^{2}$, minimum RMSE and MAPE value with significant estimates of the model parameters.
From table 12 it is clearly understood that population of different types of nematodes in the study are best fitted with polynomial models particularly quadratic. This polynomial series indicates more than one point of inflections. In case of Meloidogyne incognita the best fitted model is cubic, negative coefficient of $b_{1}$ implies that during middle of the study period infestation is decreasing compared to early half of the study.

From August to December the intensity was almost zero. Maximum infestation of Hoplolaimus indicus was during August to September and minimum was recorded during March. Helicotylenchulus dihystera intensity is increasing during first half of the study period and decreasing latter half of the study period. From August to December the Aphelechus avenae load in the soil was almost zero, maximum was found during June. Rotylenchulus reniformis decreases initially and then increases, maximum intensity was found during March. Maximum intensity of total plant parasitic nematode was during April and then decreased with time and then increased from February onwards. Total nematodes follow quadratic trend model maximum intensity was during early stage of the crop and decreases over time up to September and steady increases there after minimum number recorded during February.

As early stage nematode load in the soil is maximum so tuberose bulb should be treated properly before planting, otherwise there is a chance of crop failure. In brief, it is observed that the best fitted model is quadratic in all the cases except Aphelenchus avenae, for which best fitted model is cubic.

\section{Trend analysis of soil nematode in tuberose} using parametric model in 2014-16

In this section we took the whole study period (2014-16) for trend analysis. From table 13, it 
is clear that all the data are fitted with polynomial models like quadratic and cubic, except Rotylenchulus reniformis, total plant parasitic nematodes and total nematodes for which best fitted trend models are exponential. Nematode intensity attains maximum after rain and minimum during pick summer season that may be the reason that maximum nematode series follow non- linear model. There may be another reason that most nematode species produce $50-500$ egg per female depending on nematode species and environment but some can produce more than 1000 eggs. The length of life cycle varies considerably, depending on the nematode species, host plant and temperature of the habitat.

Table.1 Forms of different parametric model considered

\begin{tabular}{|l|l|}
\hline Trend Model & Name of the Model \\
\hline$Y_{X}=b_{0}+b_{1} x$ & Linear \\
\hline$Y_{X}=b_{0}+b_{1} x+b_{2} x^{2}$ & Quadratic \\
\hline$Y_{X}=b_{0}+b_{1} x+b_{2} x^{2}+b_{3} x^{3}$ & Cubic \\
\hline$Y_{X}=b_{0} e^{b_{1} x}$ & Exponential \\
\hline$Y_{X}=a b^{c^{x}}$ & Gompertz \\
\hline$Y_{X}=b_{0}\left(b_{1}^{x}\right)$ & Compound \\
\hline$Y_{X}=b_{0}+b_{1} \ln (x)$ & Logarithmic \\
\hline$Y_{x}=e^{b_{0}+b_{1} \ln (x)}$ & Growth \\
\hline
\end{tabular}

Table.2 Occurrence of soil nematode in tuberose (2014-15)

\begin{tabular}{|c|c|c|c|c|c|c|c|c|c|c|}
\hline & \multicolumn{5}{|c|}{ Plant parasitic nematodes } & \multicolumn{2}{|c|}{$\begin{array}{c}\text { Non-plant } \\
\text { parasitic } \\
\text { nematodes }\end{array}$} & \multirow{2}{*}{ 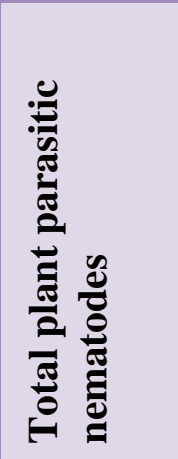 } & \multirow{2}{*}{ 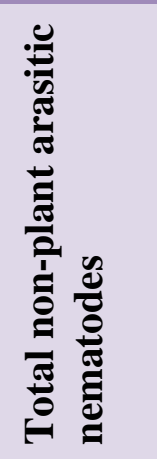 } & \multirow[b]{2}{*}{ 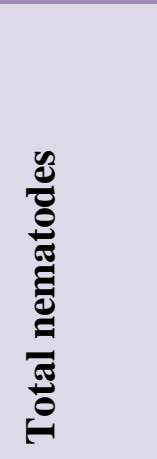 } \\
\hline & 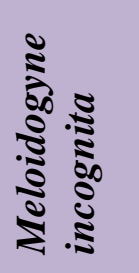 & 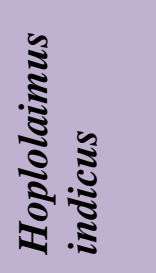 & 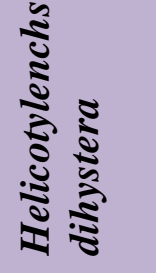 & 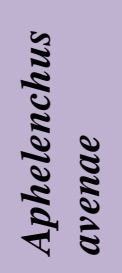 & 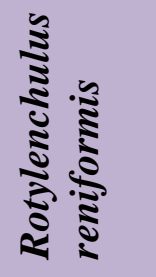 & 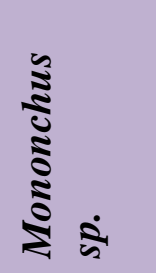 & 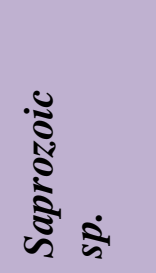 & & & \\
\hline Min. & 0.00 & 29.25 & 10.29 & 0.00 & 138.36 & 0.00 & 333.79 & 218.36 & 335.54 & 581.69 \\
\hline Max. & 12.21 & 201.25 & 56.32 & 9.80 & 998.36 & 9.39 & 712.75 & 1076.10 & 714.90 & 1697.46 \\
\hline Mean & 2.53 & 87.06 & 26.38 & 2.48 & 431.14 & 2.10 & 534.29 & 549.58 & 536.39 & 1085.97 \\
\hline SD & 4.08 & 57.66 & 12.32 & 3.65 & 278.89 & 3.50 & 99.37 & 281.42 & 100.22 & 317.24 \\
\hline Kurtosis & 0.76 & -0.69 & -0.03 & -0.20 & -0.18 & 0.12 & -0.37 & -0.69 & -0.41 & -0.86 \\
\hline Skewness & 1.46 & 0.94 & 0.75 & 1.19 & 0.95 & 1.35 & 0.20 & 0.59 & 0.20 & 0.09 \\
\hline CV & 161.26 & 66.23 & 46.70 & $\begin{array}{r}147.1 \\
8\end{array}$ & 64.69 & 166.67 & 18.60 & 51.21 & 18.68 & 29.21 \\
\hline
\end{tabular}

Note: $\mathrm{SD}=$ Standard deviation, $\mathrm{CV}=$ Coefficient of variation 
Table.3 Occurrence of soil nematode in tuberose (2015-16)

\begin{tabular}{|c|c|c|c|c|c|c|c|c|c|c|}
\hline & \multicolumn{5}{|c|}{ Plant parasitic nematodes } & \multicolumn{2}{|c|}{$\begin{array}{l}\text { Non-plant } \\
\text { parasitic } \\
\text { nematodes }\end{array}$} & \multirow{2}{*}{ 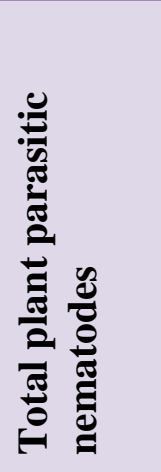 } & \multirow{2}{*}{ 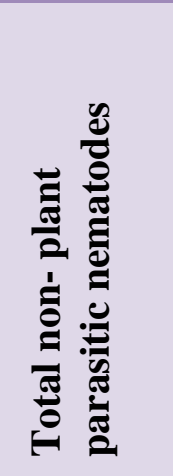 } & \multirow[b]{2}{*}{ 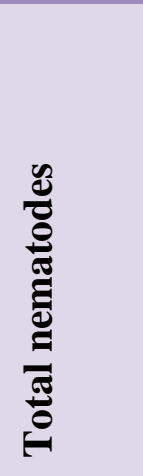 } \\
\hline & 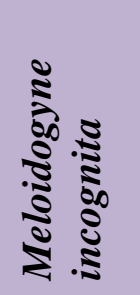 & 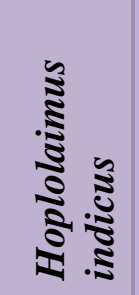 & 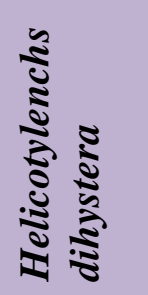 & 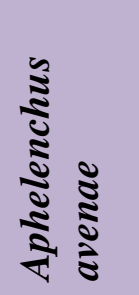 & 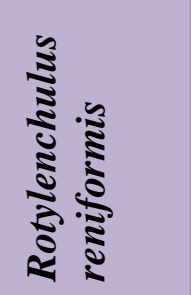 & 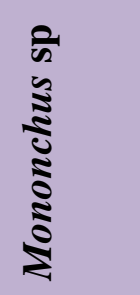 & 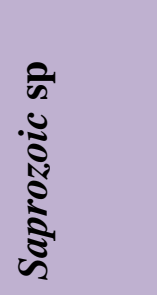 & & & \\
\hline Min. & 0.00 & 12.23 & 55.00 & 0.00 & 1002.45 & 0.00 & 358.55 & 1089.68 & 358.55 & 1566.68 \\
\hline Max. & 4.60 & 57.56 & 213.45 & 9.65 & 2334.29 & 6.36 & 1125.31 & 2429.99 & 1125.31 & 3468.40 \\
\hline Mean & 0.92 & 25.37 & 110.70 & 2.28 & 1660.38 & 0.68 & 642.64 & 1799.64 & 643.32 & 2442.96 \\
\hline SD & 1.56 & 13.45 & 54.99 & 3.61 & 485.86 & 1.65 & 216.43 & 481.46 & 216.57 & 526.15 \\
\hline Kurtosis & 0.30 & 0.87 & -0.65 & -0.11 & -1.60 & 2.72 & -0.09 & -1.57 & -0.11 & -0.90 \\
\hline Skewness & 1.35 & 1.35 & 1.03 & 1.24 & -0.07 & 2.47 & 0.83 & -0.22 & 0.82 & -0.25 \\
\hline $\mathbf{C V}$ & 169.57 & 53.02 & 49.67 & 158.33 & 29.26 & 242.65 & 33.68 & 26.75 & 33.66 & 21.54 \\
\hline
\end{tabular}

Note: $\mathrm{SD}=$ Standard deviation, $\mathrm{CV}=$ Coefficient of variation.

Table.4 Occurrence of soil nematode in tuberose (2014-16)

\begin{tabular}{|c|c|c|c|c|c|c|c|c|c|c|}
\hline & \multicolumn{5}{|c|}{ Plant parasitic nematodes } & \multicolumn{2}{|c|}{$\begin{array}{l}\text { Non-plant } \\
\text { parasitic } \\
\text { nematodes }\end{array}$} & \multirow{2}{*}{ 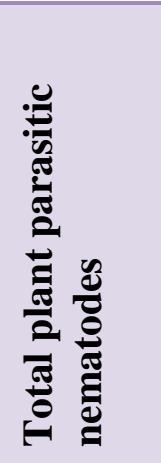 } & \multirow{2}{*}{ 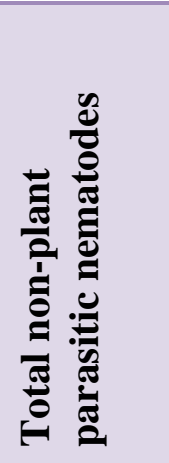 } & \multirow[b]{2}{*}{ 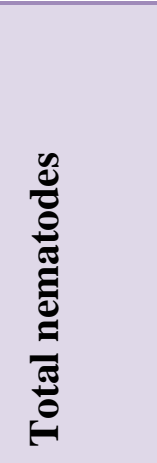 } \\
\hline & 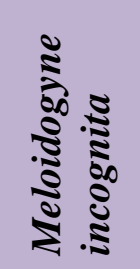 & 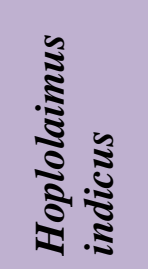 & 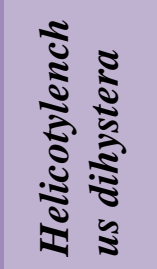 & 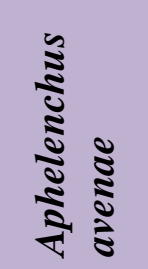 & 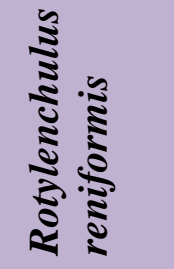 & 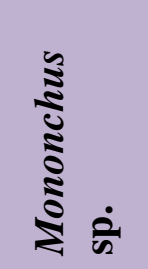 & 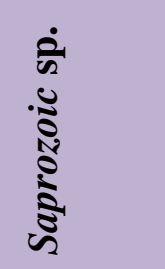 & & & \\
\hline Min. & 0.00 & 12.23 & 10.29 & 0.00 & 138.36 & 0.00 & 333.79 & 218.36 & 335.54 & 581.69 \\
\hline Max. & 12.21 & 201.25 & 213.45 & 9.80 & 2334.29 & 9.39 & 1125.31 & 2429.99 & 1125.31 & 3468.40 \\
\hline Mean & 1.73 & 56.21 & 68.54 & 2.38 & 1045.76 & 1.39 & 588.46 & 1174.61 & 589.85 & 1764.46 \\
\hline SD & 3.16 & 51.84 & 58.05 & 3.59 & 734.42 & 2.80 & 175.36 & 742.41 & 175.46 & 809.24 \\
\hline Kurtosis & 2.83 & 1.83 & 1.03 & -0.27 & -1.22 & 2.50 & 1.81 & -1.28 & 1.75 & -1.18 \\
\hline Skewness & 2.09 & 1.68 & 1.36 & 1.17 & 0.39 & 1.95 & 1.31 & 0.34 & 1.29 & 0.32 \\
\hline CV & 182.66 & 92.23 & 84.70 & 150.84 & 70.23 & 201.44 & 29.80 & 63.20 & 29.75 & 45.86 \\
\hline
\end{tabular}

Note: $\mathrm{SD}=$ Standard deviation, $\mathrm{CV}=$ Coefficient of variation 
Table.5 Micro climatic factors during experimental period in tuberose2014-15

\begin{tabular}{|l|c|c|c|c|c|c|c|c|}
\hline & $\mathbf{X}_{\mathbf{1}}$ & $\mathbf{X}_{\mathbf{2}}$ & $\mathbf{X}_{\mathbf{3}}$ & $\mathbf{X}_{\mathbf{4}}$ & $\mathbf{X}_{\mathbf{5}}$ & $\mathbf{X}_{\mathbf{6}}$ & $\mathbf{X}_{\mathbf{7}}$ & $\mathbf{X}_{\mathbf{8}}$ \\
\hline Minimum & 2.83 & 10.12 & 12.72 & 14.74 & 23.51 & 67.18 & 44.97 & 29.01 \\
\hline Maximum & 16.36 & 31.50 & 31.62 & 35.79 & 39.98 & 94.19 & 92.08 & 92.11 \\
\hline Mean & 10.06 & 24.73 & 24.33 & 27.96 & 32.47 & 83.92 & 74.38 & 60.30 \\
\hline SD & 3.46 & 6.85 & 6.05 & 5.78 & 4.54 & 8.48 & 11.73 & 11.40 \\
\hline Kurtosis & -0.56 & -0.83 & -0.90 & 0.08 & -0.53 & -0.77 & 0.39 & 2.86 \\
\hline Skewness & -0.45 & -0.78 & -0.66 & -0.87 & -0.25 & -0.61 & -0.74 & 0.01 \\
\hline CV & 34.39 & 27.70 & 24.87 & 20.67 & 13.98 & 10.10 & 15.77 & 18.91 \\
\hline
\end{tabular}

Note: $\mathrm{X}_{1}=$ Soil moisture $\%, \mathrm{X}_{2}=$ Soil temperature ${ }^{0} \mathrm{C}, \mathrm{X}_{3}=$ Ambient temperature at $7 \mathrm{am}, \mathrm{X}_{4}=$ Ambient temperature at $9 \mathrm{am}, \mathrm{X}_{5}=$ Ambient temperature at $11 \mathrm{am}, \mathrm{X}_{6}=\mathrm{RH}$ at $7 \mathrm{am}, \mathrm{X}_{7}=\mathrm{RH}$ at $9 \mathrm{am}, \mathrm{X}_{8}=\mathrm{RH}$ at $11 \mathrm{am}$

Table.6 Micro climatic factors during experimental period in tuberose in 2015-16

\begin{tabular}{|l|c|c|c|c|c|c|c|c|}
\hline & $\mathbf{X}_{\mathbf{1}}$ & $\mathbf{X}_{\mathbf{2}}$ & $\mathbf{X}_{\mathbf{3}}$ & $\mathbf{X}_{\mathbf{4}}$ & $\mathbf{X}_{\mathbf{5}}$ & $\mathbf{X}_{\mathbf{6}}$ & $\mathbf{X}_{\mathbf{7}}$ & $\mathbf{X}_{\mathbf{8}}$ \\
\hline Minimum & 3.46 & 10.12 & 11.89 & 15.65 & 22.61 & 67.12 & 48.20 & 32.22 \\
\hline Maximum & 12.91 & 31.45 & 32.35 & 34.45 & 40.03 & 92.45 & 86.72 & 74.01 \\
\hline Mean & 8.90 & 25.09 & 23.82 & 27.42 & 32.05 & 84.09 & 70.61 & 58.47 \\
\hline SD & 3.29 & 6.60 & 6.66 & 5.65 & 4.55 & 7.82 & 10.58 & 9.87 \\
\hline Kurtosis & -1.49 & 0.32 & -1.09 & -0.10 & 0.21 & -0.28 & -0.94 & 1.65 \\
\hline Skewness & -0.42 & -1.21 & -0.63 & -0.97 & -0.87 & -0.92 & -0.35 & -1.21 \\
\hline CV & 36.97 & 26.31 & 27.96 & 20.61 & 14.20 & 9.30 & 14.98 & 16.88 \\
\hline
\end{tabular}

Note: $\mathrm{X}_{1}=$ Soil moisture $\%, \mathrm{X}_{2}=$ Soil temperature ${ }^{0} \mathrm{C}, \mathrm{X}_{3}=$ Ambient temperature at $7 \mathrm{am}, \mathrm{X}_{4}=$ Ambient temperature at $9 \mathrm{am}, \mathrm{X}_{5}=$ Ambient temperature at $11 \mathrm{am}, \mathrm{X}_{6}=\mathrm{RH}$ at $7 \mathrm{am}, \mathrm{X}_{7}=\mathrm{RH}$ at $9 \mathrm{am}, \mathrm{X}_{8}=\mathrm{RH}$ at $11 \mathrm{am}$

Table.7 Micro climatic factors during experimental period in tuberose in 2014-16

\begin{tabular}{|l|c|c|c|c|c|c|c|c|}
\hline & $\mathbf{X}_{\mathbf{1}}$ & $\mathbf{X}_{\mathbf{2}}$ & $\mathbf{X}_{\mathbf{3}}$ & $\mathbf{X}_{\mathbf{4}}$ & $\mathbf{X}_{\mathbf{5}}$ & $\mathbf{X}_{\mathbf{6}}$ & $\mathbf{X}_{\mathbf{7}}$ & $\mathbf{X}_{\mathbf{8}}$ \\
\hline Minimum & 2.83 & 10.12 & 11.89 & 14.74 & 22.61 & 67.12 & 44.97 & 29.01 \\
\hline Maximum & 16.36 & 31.50 & 32.35 & 35.79 & 40.03 & 94.19 & 92.08 & 92.11 \\
\hline Mean & 9.48 & 24.91 & 24.07 & 27.69 & 32.26 & 84.00 & 72.50 & 59.38 \\
\hline SD & 3.39 & 6.65 & 6.30 & 5.66 & 4.50 & 8.07 & 11.22 & 10.59 \\
\hline Kurtosis & -0.97 & -0.41 & -1.00 & -0.13 & -0.21 & -0.62 & -0.40 & 2.86 \\
\hline Skewness & -0.38 & -0.96 & -0.63 & -0.88 & -0.54 & -0.72 & -0.48 & -0.42 \\
\hline CV & 35.76 & 26.70 & 26.17 & 20.44 & 13.95 & 9.61 & 15.48 & 17.83 \\
\hline
\end{tabular}

Note: $\mathrm{X}_{1}=$ Soil moisture $\%, \mathrm{X}_{2}=$ Soil temperature ${ }^{0} \mathrm{C}, \mathrm{X}_{3}=$ Ambient temperature at 7 am, $\mathrm{X}_{4}=$ Ambient temperature at 9 am, $\mathrm{X}_{5}=$ Ambient temperature at $11 \mathrm{am}, \mathrm{X}_{6}=\mathrm{RH}$ at $7 \mathrm{am}, \mathrm{X}_{7}=\mathrm{RH}$ at $9 \mathrm{am}, \mathrm{X}_{8}=\mathrm{RH}$ at $11 \mathrm{am}$ 
Table.8 Correlation between abiotic factors and soil nematode in tuberose in 2014-15

\begin{tabular}{|c|c|c|c|c|c|c|c|c|c|c|}
\hline & 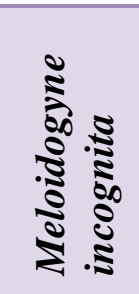 & 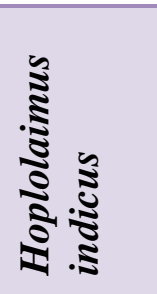 & 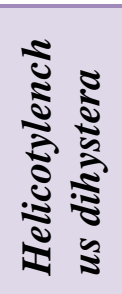 & 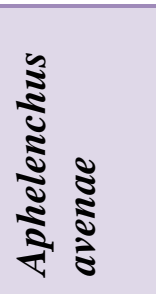 & 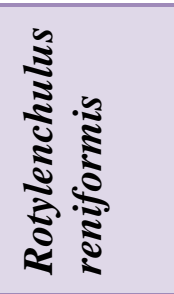 & 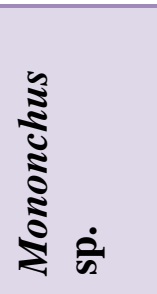 & 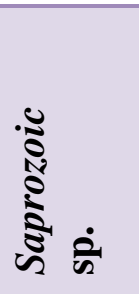 & 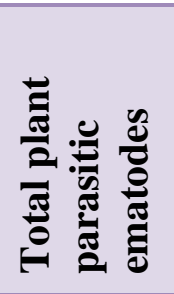 & 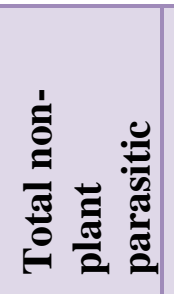 & 莺 \\
\hline$X_{1}$ & $0.46^{*}$ & $0.61^{* *}$ & $0.41^{*}$ & 0.36 & $-0.43^{*}$ & $0.43^{*}$ & 0.10 & -0.31 & 0.11 & 0.24 \\
\hline $\mathbf{X}_{2}$ & $0.55^{* *}$ & $0.67 * *$ & 0.34 & 0.4 & -0.17 & $0.51 *$ & 0.3 & -0.03 & 0.31 & 0.07 \\
\hline $\mathbf{X}_{3}$ & $0.60 * *$ & $0.69 * *$ & -0.24 & $0.49^{*}$ & 0.13 & $0.56^{* *}$ & 0.36 & 0.02 & 0.38 & 0.14 \\
\hline $\mathbf{X}_{4}$ & $0.55^{* *}$ & $0.61 * *$ & -0.29 & $0.50 *$ & 0.16 & $0.59 * *$ & 0.4 & -0.03 & $0.42^{*}$ & 0.11 \\
\hline $\mathbf{X}_{5}$ & $0.42 *$ & $0.54 * *$ & -0.37 & $0.61 * *$ & -0.32 & $0.59 * *$ & 0.34 & -0.21 & 0.35 & -0.07 \\
\hline $\mathbf{X}_{6}$ & -0.31 & -0.25 & -0.36 & 0.01 & $-0.60 * *$ & -0.02 & $-0.42 *$ & $-0.67 * *$ & $-0.41 *$ & $-0.72 * *$ \\
\hline $\mathbf{X}_{7}$ & -0.11 & -0.08 & -0.14 & 0.07 & $-0.43^{*}$ & 0.00 & $-0.43^{*}$ & $-0.45^{*}$ & $-0.43^{*}$ & $-0.53 * *$ \\
\hline $\mathbf{X}_{8}$ & -0.08 & 0.08 & -0.31 & 0.09 & -0.33 & 0.10 & -0.31 & -0.33 & -0.3 & -0.38 \\
\hline
\end{tabular}

Note:* and $* *$ denote significant at $5 \%$ and $1 \%$ level of significance respectively; $\mathrm{X}_{1}=$ Soil moisture $\%, \mathrm{X}_{2}=$ Soil temperature , $\mathrm{X}_{3}=$ Ambient temperature at $7 \mathrm{am}, \mathrm{X}_{4}=$ Ambient temperature at $9 \mathrm{am}, \mathrm{X}_{5}=$ Ambient temperature at $11 \mathrm{am}, \mathrm{X}_{6}=\mathrm{RH}$ at $7 \mathrm{am}, \mathrm{X}_{7}=$ $\mathrm{RH}$ at $9 \mathrm{am}, \mathrm{X}_{8}=\mathrm{RH}$ at $11 \mathrm{am}$

Table.9 Correlation between abiotic factors and soil nematode in tuberose in 2015-16

\begin{tabular}{|c|c|c|c|c|c|c|c|c|c|c|}
\hline & 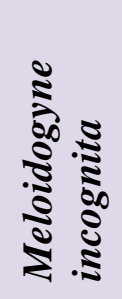 & 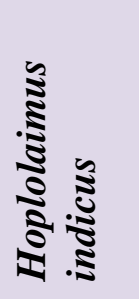 & 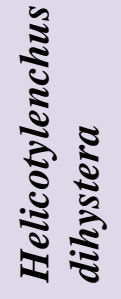 & 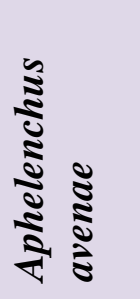 & 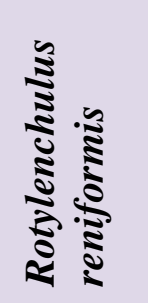 & 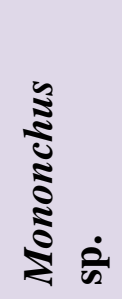 & 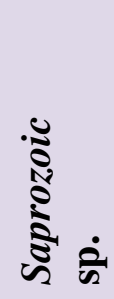 & 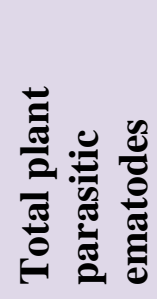 & 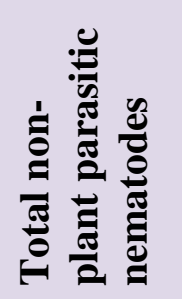 & \\
\hline$X_{1}$ & 0.13 & 0.27 & 0.35 & 0.20 & $-0.46^{*}$ & 0.37 & 0.13 & $-0.41 *$ & 0.13 & -0.32 \\
\hline $\mathbf{X}_{2}$ & 0.28 & -0.17 & -0.15 & 0.03 & $0.49 *$ & 0.27 & -0.05 & $0.47 *$ & -0.05 & $0.41^{*}$ \\
\hline $\mathbf{X}_{3}$ & $0.45^{*}$ & 0.21 & 0.10 & 0.02 & $0.45^{*}$ & 0.23 & 0.03 & $0.44 *$ & 0.03 & $0.41^{*}$ \\
\hline$X_{4}$ & 0.37 & 0.06 & 0.06 & 0.08 & 0.40 & 0.23 & 0.13 & $0.41 *$ & 0.13 & $0.43^{*}$ \\
\hline$X_{5}$ & 0.19 & 0.03 & 0.06 & 0.05 & 0.20 & 0.33 & 0.05 & 0.20 & 0.05 & 0.20 \\
\hline$X_{6}$ & -0.07 & 0.36 & -0.38 & -0.26 & $-0.52 * *$ & 0.18 & -0.08 & $-0.47 *$ & -0.08 & $-0.46^{*}$ \\
\hline $\mathbf{X}_{7}$ & -0.01 & -0.19 & -0.07 & 0.35 & -0.29 & 0.12 & -0.39 & -0.31 & -0.39 & $-0.44 *$ \\
\hline $\mathbf{X}_{8}$ & -0.05 & 0.12 & -0.20 & -0.36 & -0.17 & -0.04 & -0.24 & -0.14 & -0.24 & -0.23 \\
\hline
\end{tabular}

Note:* and ** denote significant at $5 \%$ and $1 \%$ level of significance respectively; $\mathrm{X}_{1}=$ Soil moisture $\%, \mathrm{X}_{2}=$ Soil temperature ,$X_{3}=$ Ambient temperature at $7 \mathrm{am}, X_{4}=$ Ambient temperature at $9 \mathrm{am}, X_{5}=$ Ambient temperature at $11 \mathrm{am}, X_{6}=\mathrm{RH}$ at $7 \mathrm{am}$, $\mathrm{X}_{7}=\mathrm{RH}$ at $9 \mathrm{am}, \mathrm{X}_{8}=\mathrm{RH}$ at $11 \mathrm{am}$ 
Table.10 Correlation between abiotic factors and soil nematode in tuberose in 2014-16

\begin{tabular}{|c|c|c|c|c|c|c|c|c|c|c|}
\hline & 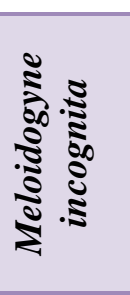 & 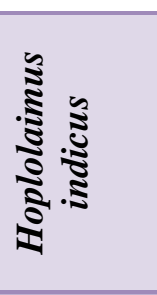 & 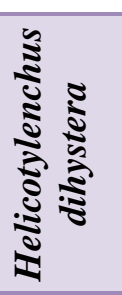 & 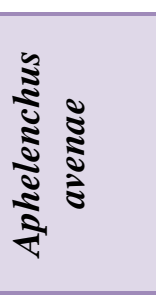 & 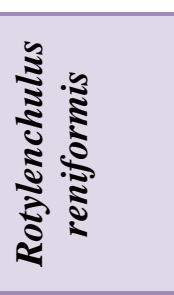 & 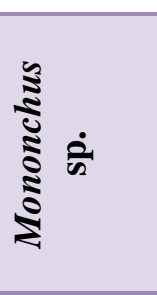 & 莺 & 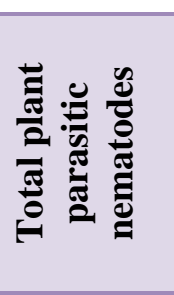 & 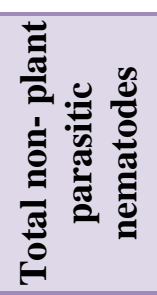 & 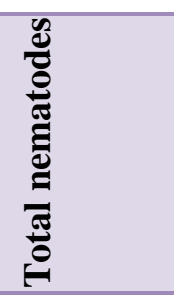 \\
\hline $\mathbf{X}_{1}$ & $0.30^{*}$ & $0.48 * *$ & 0.01 & 0.28 & $-0.37 * *$ & $0.42 * *$ & 0.05 & $0.33^{*}$ & 0.05 & $-0.29^{*}$ \\
\hline $\mathbf{X}_{2}$ & $0.42 * *$ & $0.34 *$ & -0.08 & 0.22 & 0.15 & $0.39 * *$ & 0.06 & 0.17 & 0.07 & 0.17 \\
\hline$X_{3}$ & $0.49^{* *}$ & $0.36^{*}$ & -0.11 & 0.22 & 0.10 & $0.41 * *$ & 0.10 & 0.12 & 0.11 & 0.13 \\
\hline $\mathbf{X}_{4}$ & $0.46^{* *}$ & $0.36^{*}$ & -0.04 & 0.21 & 0.06 & $0.45^{* *}$ & 0.18 & 0.08 & 0.18 & 0.12 \\
\hline $\mathbf{X}_{5}$ & $0.33^{*}$ & $0.32 *$ & 0.1 & 0.28 & -0.03 & $0.47 * *$ & 0.11 & 0.02 & 0.12 & 0.01 \\
\hline$X_{6}$ & -0.22 & -0.11 & 0.14 & -0.13 & -0.27 & 0.04 & -0.17 & -0.27 & -0.17 & -0.28 \\
\hline $\mathbf{X}_{7}$ & -0.03 & -0.03 & -0.17 & 0.20 & $-0.32 *$ & 0.08 & $-0.4 * *$ & $-0.32 *$ & $-0.4 * *$ & $-0.38 * *$ \\
\hline $\mathbf{X}_{8}$ & 0.08 & 0.11 & -0.01 & -0.21 & -0.19 & -0.08 & -0.25 & -0.18 & -0.25 & -0.22 \\
\hline
\end{tabular}

Note:* and ** denote significant at $5 \%$ and $1 \%$ level of significance respectively; $\mathrm{X}_{1}=$ Soil moisture $\%, \mathrm{X}_{2}=$ Soil temperature , $\mathrm{X}_{3}=$ Ambient temperature at $7 \mathrm{am}, \mathrm{X}_{4}=$ Ambient temperature at $9 \mathrm{am}, \mathrm{X}_{5}=$ Ambient temperature at $11 \mathrm{am}, \mathrm{X}_{6}=\mathrm{RH}$ at $7 \mathrm{am}, \mathrm{X}_{7}=$ $\mathrm{RH}$ at $9 \mathrm{am}, \mathrm{X}_{8}=\mathrm{RH}$ at $11 \mathrm{am}$

Table.11 Trend analysis of soil nematode in tuberose using parametric model in 2014-15

\begin{tabular}{|c|c|c|c|c|c|c|c|c|}
\hline \multirow[t]{2}{*}{ Nematodes } & \multirow{2}{*}{$\begin{array}{c}\text { Best } \\
\text { fitted } \\
\text { Trend model }\end{array}$} & \multirow[t]{2}{*}{ RMSE } & \multirow[t]{2}{*}{ MAPE } & \multirow[t]{2}{*}{ Adj. $\mathbf{R}^{2}$} & \multicolumn{4}{|c|}{ Parameter estimates of trend model } \\
\hline & & & & & $\mathbf{b}_{0}$ & $\mathbf{b}_{1}$ & $\mathbf{b}_{2}$ & $\mathbf{b}_{3}$ \\
\hline $\begin{array}{l}\text { Meloidogyne } \\
\text { incognita }\end{array}$ & Exponential & 0.65 & 39.58 & 0.57 & $\begin{array}{l}2.76^{* *} \\
(0.48)\end{array}$ & $\begin{array}{c}-0.07 * * \\
0.01)\end{array}$ & & \\
\hline $\begin{array}{l}\text { Hoplolaimus } \\
\text { indicus }\end{array}$ & Exponential & 40.42 & 41.89 & 0.64 & $\begin{array}{c}247.63 * * \\
(45.19)\end{array}$ & $\begin{array}{c}-0.11^{* *} \\
(0.01)\end{array}$ & & \\
\hline $\begin{array}{l}\text { Helicotylenchus } \\
\text { dihystera }\end{array}$ & Quadratic & 9.07 & 32.85 & 0.38 & $\begin{array}{l}26.05^{*} \\
(6.48)\end{array}$ & $\begin{array}{l}-1.70 \\
(0.96)\end{array}$ & $\begin{array}{l}0.11^{*} \\
(0.04)\end{array}$ & \\
\hline $\begin{array}{l}\text { Aphelenchus } \\
\text { avenae }\end{array}$ & Cubic & 4.24 & 81.31 & 0.34 & $\begin{array}{c}-4.97 * * \\
(4.41)\end{array}$ & $\begin{array}{l}4.38 * * \\
(1.49)\end{array}$ & $\begin{array}{l}-0.42 \\
(0.14)\end{array}$ & $\begin{array}{l}0.01 * * \\
(0.004)\end{array}$ \\
\hline $\begin{array}{l}\text { Rotylenchulus } \\
\text { reniformis }\end{array}$ & Quadratic & 148.05 & 28.57 & 0.79 & $\begin{array}{l}748.76^{* *} \\
(105.62)\end{array}$ & $\begin{array}{c}-118.49 * * \\
(19.46)\end{array}$ & $\begin{array}{l}5.80 * * \\
(0.76)\end{array}$ & \\
\hline Mononchus sp. & Cubic & 0.55 & 47.00 & 0.60 & $\begin{array}{l}-0.25 \\
0.58)\end{array}$ & $\begin{array}{l}0.87 * * \\
(0.19)\end{array}$ & $\begin{array}{c}-0.09 * * \\
(0.02)\end{array}$ & $\begin{array}{c}0.002 * * \\
(0.003)\end{array}$ \\
\hline Mononchus sp. & Exponential & 89.73 & 13.06 & 0.11 & $\begin{array}{c}615.99 * * \\
(51.72)\end{array}$ & $\begin{array}{c}-0.013 * \\
(0.01)\end{array}$ & & \\
\hline Saprozoic sp. & Quadratic & 143.97 & 25.94 & 0.71 & $\begin{array}{l}920.21 * * \\
(102.66)\end{array}$ & $\begin{array}{c}-111.60 * * \\
(18.91)\end{array}$ & $\begin{array}{l}5.02 * * \\
(0.74)\end{array}$ & \\
\hline $\begin{array}{l}\text { Total plant } \\
\text { Parasitic }\end{array}$ & Power & 88.57 & 12.91 & 0.14 & $\begin{array}{c}660.25^{* *} \\
(70.55)\end{array}$ & $\begin{array}{l}-0.10^{*} \\
(0.04)\end{array}$ & & \\
\hline Total nematodes & Quadratic & 188.18 & 16.21 & 0.59 & $\begin{array}{c}1591.60 * * \\
(134.15)\end{array}$ & $\begin{array}{c}-132.28 * * \\
(24.72)\end{array}$ & $\begin{array}{l}5.62 * * \\
(0.96)\end{array}$ & \\
\hline
\end{tabular}

Note:* and ** denote significant at 5\% and $1 \%$ level of significance respectively and number inside parentheses indicates standard error of the corresponding parameter estimates 
Table.12 Trend analysis of soil nematode in tuberose using parametric model in 2015-16

\begin{tabular}{|c|c|c|c|c|c|c|c|c|}
\hline \multirow[t]{2}{*}{ Nematodes } & \multirow{2}{*}{$\begin{array}{c}\text { Best } \\
\text { fitted } \\
\text { trend model }\end{array}$} & \multirow[t]{2}{*}{ RMSE } & \multirow[t]{2}{*}{ MAPE } & \multirow[t]{2}{*}{ Adj. $\mathbf{R}^{2}$} & \multicolumn{4}{|c|}{ Parameter estimates of trend model } \\
\hline & & & & & $\mathbf{b}_{0}$ & $\mathbf{b}_{1}$ & $\mathbf{b}_{2}$ & $\mathbf{b}_{3}$ \\
\hline $\begin{array}{l}\text { Meloidogyne } \\
\text { incognita }\end{array}$ & Quadratic & 0.45 & 29.36 & 0.48 & $\begin{array}{r}2.19 * * \\
(0.27)\end{array}$ & $\begin{array}{r}-0.17 * * \\
(0.05)\end{array}$ & $\begin{array}{r}0.004 * \\
(0.002)\end{array}$ & \\
\hline $\begin{array}{l}\text { Hoplolaimus } \\
\text { indicus }\end{array}$ & Quadratic & 1.21 & 18.69 & 0.19 & $\begin{array}{l}4.25^{*} \\
(0.75)\end{array}$ & $\begin{array}{r}0.23 \\
(0.14)\end{array}$ & $\begin{array}{r}-0.01 * \\
(0.005)\end{array}$ & \\
\hline $\begin{array}{l}\text { Helicotylenchus } \\
\text { dihystera }\end{array}$ & Quadratic & 2.12 & 16.32 & 0.15 & $\begin{array}{r}57.27 \\
(49.11)\end{array}$ & $\begin{array}{l}17.16 \\
(9.05)\end{array}$ & $\begin{array}{r}-0.74^{*} \\
(0.35)\end{array}$ & \\
\hline $\begin{array}{l}\text { Aphelenchus } \\
\text { avenae }\end{array}$ & Cubic & 1.32 & 72.03 & 0.12 & $\begin{array}{r}3.16 \\
(6.45) \\
\end{array}$ & $\begin{array}{r}1.60 \\
(2.19)\end{array}$ & $\begin{array}{r}-0.19 \\
(0.20)\end{array}$ & $\begin{array}{l}0.005^{*} \\
(0.005)\end{array}$ \\
\hline $\begin{array}{l}\text { Rotylenchulus } \\
\text { reniformis }\end{array}$ & Quadratic & 168.05 & 29.57 & 0.49 & $\begin{array}{r}2856.60 * * \\
(238.33)\end{array}$ & $\begin{array}{r}-250.74 * * \\
(43.93)\end{array}$ & $\begin{array}{r}9.28 * * \\
(1.70)\end{array}$ & \\
\hline Mononchus sp. & Quadratic & 1.98 & 38.03 & 0.19 & $\begin{array}{r}0.50 \\
(0.34)\end{array}$ & $\begin{array}{r}0.12 * * \\
(0.06)\end{array}$ & $\begin{array}{r}-0.005^{*} \\
(0.001)\end{array}$ & \\
\hline Mononchus sp. & Quadratic & 224.21 & 23.65 & 0.22 & $\begin{array}{l}528.76^{*} \\
(147.37)\end{array}$ & $\begin{array}{r}26.95 \\
(27.16)\end{array}$ & $\begin{array}{l}-1.09 \\
(1.05)\end{array}$ & \\
\hline Saprozoic sp. & Quadratic & 237.01 & 21.02 & 0.42 & $\begin{array}{r}2935.80^{* * *} \\
(270.71)\end{array}$ & $\begin{array}{r}-229.94 * * \\
(49.89)\end{array}$ & $\begin{array}{r}8.37 \text { ** } \\
(1.93)\end{array}$ & \\
\hline Total plant Parasitic & Quadratic & 225.01 & 23.96 & 0.22 & $\begin{array}{l}528.14^{*} \\
(147.36)\end{array}$ & $\begin{array}{r}27.31 \\
(20.12)\end{array}$ & $\begin{array}{l}-1.11 \\
(1.02)\end{array}$ & \\
\hline Total nematodes & Quadratic & 412.03 & 14.20 & 0.31 & $\begin{array}{r}3419.50 * \\
(289.39)\end{array}$ & $\begin{array}{r}-186.10^{* *} \\
(53.34)\end{array}$ & $\begin{array}{r}6.61 * * \\
(2.07)\end{array}$ & \\
\hline
\end{tabular}

Note:* and $* *$ denote significant at $5 \%$ and $1 \%$ level of significance respectively and number inside parentheses indicates standard error of the corresponding parameter estimates

Table.13 Trend analysis of soil nematode in tuberose using parametric model in 2014-16

\begin{tabular}{|c|c|c|c|c|c|c|c|c|}
\hline \multirow[t]{2}{*}{ Nematodes } & \multirow{2}{*}{$\begin{array}{c}\text { Best fitted } \\
\text { trend } \\
\text { model }\end{array}$} & \multirow[t]{2}{*}{ RMSE } & \multirow[t]{2}{*}{ MAPE } & \multirow[t]{2}{*}{ Adj. $\mathbf{R}^{2}$} & \multicolumn{4}{|c|}{ Parameter estimates of trend model } \\
\hline & & & & & $\mathbf{b}_{0}$ & $\mathbf{b}_{1}$ & $\mathbf{b}_{2}$ & $\mathbf{b}_{3}$ \\
\hline $\begin{array}{l}\text { Meloidogyne } \\
\text { incognita }\end{array}$ & Cubic & 0.61 & 44.25 & 0.43 & $\begin{array}{r}3.44 * * \\
(0.39)\end{array}$ & $\begin{array}{r}-0.30 * * \\
(0.07)\end{array}$ & $\begin{array}{r}0.01 * * \\
(0.01)\end{array}$ & $\begin{array}{r}0.003 * * \\
(0.001)\end{array}$ \\
\hline $\begin{array}{l}\text { Hoplolaimus } \\
\text { indicus }\end{array}$ & Cubic & 1.26 & 14.58 & 0.81 & $\begin{array}{r}15.09 * * \\
(0.82)\end{array}$ & $\begin{array}{r}-0.81 * * \\
(0.14)\end{array}$ & $\begin{array}{r}0.02 * * \\
(0.01)\end{array}$ & $\begin{array}{r}0.0002 * \\
(0.001)\end{array}$ \\
\hline $\begin{array}{l}\text { Helicotylenchus } \\
\text { dihystera }\end{array}$ & Cubic & 1.64 & 15.94 & 0.72 & $\begin{array}{r}6.43 * * \\
(1.07)\end{array}$ & $\begin{array}{r}-0.66 * * \\
(0.19)\end{array}$ & $\begin{array}{r}0.05 * * \\
(0.01)\end{array}$ & $\begin{array}{r}0.007 * * \\
(0.002)\end{array}$ \\
\hline $\begin{array}{l}\text { Aphelenchus } \\
\text { avenae }\end{array}$ & Quadratic & 0.95 & 74.42 & 0.01 & $\begin{array}{r}1.78 * * \\
(0.62)\end{array}$ & $\begin{array}{r}-0.02 \\
(0.10)\end{array}$ & $\begin{array}{r}0.002 \\
(0.005)\end{array}$ & \\
\hline $\begin{array}{l}\text { Rotylenchulus } \\
\text { reniformis }\end{array}$ & Exponential & 501.57 & 69.53 & 0.49 & $\begin{array}{r}213.24 * * \\
(40.74)\end{array}$ & $\begin{array}{r}0.05^{* *} \\
(0.01)\end{array}$ & & \\
\hline Mononchus sp. & Quadratic & 0.71 & 48.11 & 0.12 & $\begin{array}{r}1.98 * * \\
(0.33)\end{array}$ & $\begin{array}{r}-0.06 \\
(0.03)\end{array}$ & $\begin{array}{r}0.001 \\
(0.001)\end{array}$ & \\
\hline Mononchus sp. & Cubic & 3.12 & 9.83 & 0.10 & $\begin{array}{r}26.85^{* * *} \\
(2.04)\end{array}$ & $\begin{array}{l}-0.80 * \\
(0.36)\end{array}$ & $\begin{array}{r}0.04 * \\
(0.017)\end{array}$ & $\begin{array}{r}0.005^{*} \\
(0.0004)\end{array}$ \\
\hline Saprozoic sp. & Exponential & 507.97 & 53.99 & 0.49 & $\begin{array}{r}333.21 * * \\
(56.75)\end{array}$ & $\begin{array}{r}0.04 * * \\
(0.06)\end{array}$ & & \\
\hline $\begin{array}{l}\text { Total plant } \\
\text { Parasitic }\end{array}$ & Cubic & 3.12 & 9.90 & 0.09 & $\begin{array}{r}26.95^{* *} \\
(2.03)\end{array}$ & $\begin{array}{r}-0.80^{*} \\
(0.36)\end{array}$ & $\begin{array}{r}0.04 * \\
(0.017)\end{array}$ & $\begin{array}{r}0.005^{*} \\
(0.0005)\end{array}$ \\
\hline Total nematodes & Exponential & 843.86 & 38.34 & 0.26 & $\begin{array}{r}851.89 * * \\
(102.36)\end{array}$ & $\begin{array}{r}0.02 * * \\
(0.01)\end{array}$ & & \\
\hline
\end{tabular}

Note:* and ** denote significant at $5 \%$ and $1 \%$ level of significance respectively and numbers inside parentheses indicate standard error of the corresponding parameter estimates 
Meloidogyne incognita and Hoplolaimus indicus decrease over time during study period. Maximum infestation of Helicotylenchulus dihystera occurred during the second year. Rotylenchulus reniformis intensity is increasing exponentially over time. It warns farmersthat they should opt for new planting material in time for bumper production of tuberose flower for their better livelihood. Maximum intensity of Mononchus $s p$. was found during June-July and in winter season its intensity was almost zero. Minimum intensity of Saprozoic sp. was found during last of August maximum during second year April.

In conclusion, analysis of data reveals that maximum intensity of incidence of most of the soil borne nematodes is found during rainy season. Huge variations in occurrence are found among the seven types of nematodes under study. Variations in nematode loads under the same experimental area clearly indicate that microclimatic conditions required for growth of different nematode populations are not the same; these might be having different specificity, which needs to be studied separately for efficient management of different types of soil borne nematodes.

Not all the abiotic factors are found equally important for the different nematode species uniformly in first, second and also during the whole two years which indicates the requirement of further study in more consecutive years to get more accurate findings. There is still a need to further study non-linear form of association between nematodes and various abiotic factors as only linear association was considered here. Fitting of parametric trend models reveals that mostly polynomial and in a few cases exponential trend models are suitable for nematode incidences in tuberose.

\section{References}

Anonymous. 2015. Indian Horticulture Database, Ministry of agriculture, government of India.

Bose, T. K. (1995). Commercial Flowers. Nayaprokash, Calcutta.

Christie, J R. and Perry, V. G. (1951). Removing nematode from soil. Proceeding of Helminthological Society of Washington 18: 106-108.

Cobb, N. A. (1918). Estimating the nema population of the soil with special reference to the sugar beet and root gall nemas. Heteroderra sebaebtii, Schmidt and Heterodera radicicola (Greef) Mueller and with a description of Tylencholaimus aequalin. Agricultural Technological Circular (1). Bureae of Plant Industry, U. S. Dept. Agric. No. 1.

Das, T. K., Mitra, A. K. and Sarkar, S .C. (1988). Economics of tuberose cultivation in Nadia District (West Bengal). Economic Affairs. 33(2): 103-106.

Haque, M. A., Miah, M. A. M., Hossain, S., and Sharifuzzaman, S. M. (2012). Agroeconomic analysis of tuberose cultivation in selected areas of Bangladesh. Bangladesh Journal of Agricultural Research. 37(3): 457464.

Jayraman, V., Rajendra, G. and Muthukrishna, T. S. 1975. Occurrence of root knot nematode in Polianthes tuberosa L, in Tamil Nadu. Indian Journal of Nematology, 5: 101-102.

Khan, M. R and Pal, A. K. (2001). Plant parasitic nematode associated with tuberose (Polianthes tuberosa L.) in West Bengal. Annals of plant protection science. 9(2): 305-366.

Khan, M. R. and Pal, A. K. 2001. Plant parasitic nematode associated with tuberose (Polianthes tuberosa L.) in 
West Bengal. Annals of Plant Protection Science. 9(2): 305-366.

Khan, M. R., Shit, S., Pal. A. K. and Biswas, B. (2005). Integrated approach for management of foliar nematode, Aphelenchoides besseyi infecting tuberose in West Bengal, India. International Journal of Nematology. 15(1): 30-34.

Kundu, M., Meheta, S. and Sethi, N. (2007). Exploring floriculture potential in Haryana. Asian Journal of Horticulture. 2(1): 227-230.

Lambshead, P. J. D. (2004). Marine nematode biodiversity. In: Chen ZX, Chen SY \& Dickson DW (Eds.). Nematology, Advances and Perspectives ACSETUP Book Series.

Mitra, A., Das, T. K., Sarker, S. C. and Bhattacharya, K. K. (1989). Some aspects of tube-rose marketing in Nadia District (West Bengal), a case study. Agricultural Marketing. 32(3): 36-40.

Montasser, S. A. (1995). Reaction of certain flower bulb plants to root knot nematode, Meloidogyne incognita. Pakistan Journal of Nematology. 13(2): 99-102.

Pal, P. (2011). Modeling Pest Incidences in Some Agricultural Crops, Thesis Submitted to the Bidhan Chandra Krishi Viswavidyalaya under Department of Agricultural Statistics.
Patel, M. G., Patel, G. P., Shekh, A. M., Patel, J. R., Patel, H. R. and Patel, M .J. (1999). Effect of abiotic weather on twig damage in amla (Emblica officinalis) by Betousastylophora. Indian Journal of Agricultural Sciences. 69(10): 715-717.

Rajendran, G. and Muthukrishnan, T. S. 1980. Nat. sem. Prodn. Tech. Flower Crops, Tamilnadu Agricultural University, Coimbatore, Pp.111-2

Rao, M.S., Shylaja, M. and Naik. D. 2003. Management of nematode induced wilt disease complex intuberose (Polianthes tuberosa L.) cultivar prajwal using Pochonia chlamydosporia (Verticillium chlamydosporium) and Trichoderma harzianum. Journal of Ornamental Horticulture New Series, 6(4): 341346.

Srivastava, K.P. (1993). A Text Book of Applied Entomology, Vol. 11, Kalyani Publishers, India.55-309.

Usman, M. and Ashfaq, M. (2013). Economics analysis of tuberose production in Punjab, Pakistan. Sarhad Journal of Agriculture.29(2): 279-284.

Vaze, S. V. (2000). Indian essential oil industry present and future. Journal of Medicinal and Aromatic Plant Sciences. 22(1B): 186-191.

\section{How to cite this article:}

Herojit Singh, Sh., Md. Noman, Kushal Roy, Soumik Dey, Lakshmi Narsimhaiah, Pramit Pandit and Sahu, P.K. 2019. A Study on Association with Abiotic Factors and Modelling Incidence of Soil Borne Nematodes in Tuberose (Polianthes tuberosa L.). Int.J.Curr.Microbiol.App.Sci. 8(02): 3127-3140. doi: https://doi.org/10.20546/ijcmas.2019.802.366 